\title{
The Many Faces of Multiple Chemical Sensitivity
}

\author{
Alison Johnson* \\ Chair of the Chemical Sensitivity Foundation, UK
}

Submission: October 23, 2018; Published: November 13, 2018

*Corresponding author: Alison Johnson, Chair of the Chemical Sensitivity Foundation, UK

\section{Mini Review}

Statistics are a vital part of any scientific investigation of a serious disease, but it is important to supplement them by stories that convey the human tragedy behind the numbers on a page. Countless cancer researchers were motivated to join the field because they had lost a loved one to the disease. Major research into the mechanisms of multiple chemical sensitivity (MCS) will occur only when researchers decide that MCS is not simply a bizarre condition that might give someone a migraine headache or joint pains or a rash but is in fact a disease that can make it extremely difficult for a person to find a place to work that doesn't make them sick or a place to live where they will not experience constant symptoms. In a disturbing number of cases, suicide is the outcome when people cannot keep working or find a place to live. A former Shakespeare professor described his difficult situation with these eloquent words in my book Amputated.

Lives: Coping with Chemical Sensitivity: I have been told that early retirement is the American dream. Early retirement because of disability and a chronic, progressive illness is nothing but a bad dream, involving the loss of family, home, career, friends, mobility, income, and one's health-almost everything one holds precious.

The psychological toll on people who have been highly productive members of society and then suddenly find themselves unable to work is enormous. For my first documentary about MCS, I filmed Randa, who worked in a land-use planning office in California before she developed chemical sensitivity after a new carpet was installed. She reported, "I haven't worked for over ten years now, and that really does a job on your self-esteem". It's now been twenty-eight years that Randa has been unable to work.

A very successful painting contractor named Richard also had to give up his career because work-place exposures sensitized him to a wide variety of chemicals. He too found it devastating not to be able to keep working: I think especially as a man, not being able to work was very difficult. For all of my adult life, I guess I had identified with what I was doing for a job and had identified with my role as a business owner, someone who was providing employment for other people, someone who was performing a service for people, someone who got a big fat paycheck when the job was done.

When Michael, who owned a large tree and pesticide business and sprayed over 100,000 gallons of pesticide every year, developed MCS, he also found that being unable to work had a profound impact upon his sense of personal worth: People-my wife, my family, other people, my brother especiallyused to complain about what a workaholic I was, how I was just unbelievably driven, I would never stop. I would work weekends, I would work till dark. I just couldn't get enough. Going from being a workaholic to wondering how you're going to provide for your wife and your two children is pretty tough to take, especially as a male in this society. Society expects you to provide for your family, and people look at you strangely when you don't seem to be working your normal forty hours or more.

Randa, Richard, and Michael developed MCS while working in jobs with varying levels of chemical exposures of the type that many Americans experience. During the waning years of the twentieth century and the first few years of the twenty-first century, however, particularly large exposures to toxic chemicals occurred because of three cataclysmic events that produced chemical sensitivity in large groups of people. These events that led to the development of MCS in so many Americans, many of them young men and women in peak physical condition, were the Exxon Valdez oil spill in 1989, the first Gulf War in 1991, and the terrorist attacks on the World Trade Center in 2001.

One man hired to help in the Exxon Valdez clean-up was a construction worker named Robert Bunker, who developed chemical sensitivity after his exposure to the toxic oil and the chemicals used in the clean-up. He later described the difficult working conditions on the beaches: All day long we were wallowing in oil. We were falling down all the time.... The rocks were kind of like bowling balls covered with oil. It was a big slippery mess. After the first few days, I was having nightmares that I was drowning in oil.

Part of the plan for removing the oil from the beaches consisted of giving the clean-up workers "pom-poms," bunches 
of strands of absorbent material that resembled a cheerleader's pom-pom. The workers were supposed to wipe the oil off the rocks with these absorbent pom-poms, which they would put into plastic bags. Greta, a college student who joined the clean-up effort during her summer vacation, later described what it was like to try to clean the oil off the rocks using these pom-poms: We would sit down on the rocks while we were working because it was hard to bend down for hour after hour. There were fumes coming off the oily rocks. ... People were getting light-headed and dizzy and nauseous from the oil fumes; we sometimes felt like we might pass out. They had to take one person off the beach because she was starting to hallucinate. . . We were always sitting in oil, and the odor would give us headaches. When we leaned down to work, oil would often splatter on our faces and sometimes our wrists would get exposed. We couldn't pull off our gloves to eat without ending up with oil on our hands and on our food.

This heavy and prolonged exposure to toxic crude oil had a lasting effect on Greta's life, as she later recounted: One of the things that has affected my life in a major way is the chemical sensitivity I developed after the oil-spill cleanup. I always end up with a headache if I use hair spray, and I can't use perfume now because it gives me a headache and often makes me feel angry. Before I worked on the oil spill, I could paint my nails and use polish remover. Now I can't stand it when my daughter uses polish remover. I can't use white-out because it makes me feel sick and headachey and my chest starts to tighten. I have to avoid gasoline and diesel. My parents and my sister who worked the spill with me can't use perfume now either, and we all have to be very careful what cleaning products we use.

The Potter brothers-Roger, Mike, and Paul-were construction workers who had been having trouble finding enough work after the Alaskan pipeline was finished, so they quickly signed on to help in the cleanup operation. Roger was the lucky one of the three brothers and twenty years after the spill he had not developed any apparent lasting health effects from his clean-up work. His brother Mike was not so lucky, as he later recounted: We felt nauseated all the time we were working out there on the beaches, and headaches were rampant.... Then in addition to all the oil we were exposed to, there were a bunch of chemicals that we used. We would request and request that we be given the hazardous chemical plat that was supposed to be on top of the containers of chemicals, but we never could find out what ingredients were in the containers. We didn't have more than a name on the container. ... We nicknamed one chemical Agent Orange. One of the things it was used for was to wash the oil off the boats and skiffs. It was eating the membranes in people's noses. On our second or third R\&R, word was getting out that if you are asked to work around this chemical, you should refuse to do it.

About three years after the spill, Mike started developing troublesome health problems that included some serious memory loss problems. Some growths erupted on his arms that resembled huge warts that were about $3 / 4$ " thick and about the size of a silver dollar. He also started having blackout spells and developed serious fatigue. In addition, he noticed that exposure to cleaning solvents made his arthritis worse. Chemical sensitivity was an even greater problem for the youngest brother, Paul, as Mike recounted after his brother's early death: We were picking up debris like dead oil-soaked wildlife that gave off a terrible rotten stench. We put this stuff in plastic bags to be picked up by a little barge, and these bags were sitting on the beaches in the hot sun. Usually the tops were twisted, but when Paul picked up this one bag, the top swirled open and gases poured out onto his face. He staggered around and said he couldn't see, so some guys had to grab him. They sent him to Anchorage on a helicopter, and he spent several days in a hospital there. The exposure kind of paralyzed his breathing. He got some of the stuff in one of his eyes and almost lost it; he was actually blind for a while... After that incident, almost any chemical would cause Paul to feel nauseated.

Paul's widow recounted how the products that he had regularly used in his carpentry work started bothering him after his exposure on the oily beaches: There were at least four times that he had to get medical attention because of exposure to something toxic. One time when he was putting a sealant on a deck, he got really sick and dizzy, so they had to take him to a clinic. They called a poison hot line and hooked him up to IVs to get him stabilized. Sometimes he would have a milder reaction, but he would still end up stuck in bed for a couple of days with a violent headache, feeling yucky and kind of weak. He would react to almost anything that was petroleum based. Once when we were painting an apartment and using an oil-based primer on the walls, he almost passed out into the tray of paint. He had never reacted to things like that before Exxon Valdez. ... .At the time Paul died, the two of us were working as caretakers for an apartment complex. The week before he died he told me that the gas fumes from the snow blower were starting to make him sick. . .. It was only a half hour after he came in from snow blowing one day that he had a massive heart attack. He died in the ambulance on the way to the hospital. His doctor said that the snow blower gas fumes were most likely what had killed him. Paul was only forty-four when he died.

The soldiers who fought in the 1991 Gulf War also found themselves surrounded by a wide-range of chemicals on what was termed by some to have been the most toxic battlefield in history. The troops were exposed to a wide range of toxins, including nerve agents, pyridostigmine bromide (PB) pills used as a prophylactic against potential chemical weapons attacks, oil well fires, depleted uranium, pesticides, and anthrax vaccine. In November 2000 the American Journal of Epidemiology published an article that indicated that over 34 percent of those who served in the Gulf War-over 200,000 veterans-are now chronically ill [1].

Almost all the veterans whom I filmed for my documentary Gulf War Syndrome: Aftermath of a Toxic Battlefield now suffer 
from an extreme sensitivity to petroleum products, a sensitivity that they never had before the war. And this sensitivity seems to have spread over the years to many other chemical substances, such as fragrances, fresh paint, cleaning products, pesticides, and cigarette smoke. The following passages from my GWS video illustrate the range of the problems now facing veterans who fought in the Gulf War:

I had spent eight years in the 82nd Airborne Division as a paratrooper, so I had had extensive exposure to jet fuel and jet fumes, and these things had never bothered me. But having spent forty-five days in the area where the oil wells were burning, breathing the noxious fumes on a daily basis, now just the smell of diesel fuel makes me severely nauseated, dizzy, and very sick. I try to avoid getting behind school buses because diesel exhaust really bothers me, as do other odors and smells. Perfumes are also a problem; I don't wear any type of cologne because it makes me nauseous.

I couldn't pump my own gas ... the gas fumes would make me vomit. ... If I breathed automobile fumes, truck fumes, again I'm nauseous, trying to not vomit. I have problems breathing on buses because of the diesel fumes and to some extent with cars because of the petrol fumes. I have problems using household disinfectants and chemicals because it causes my airways to close, and it causes me to start choking.

Margaret Wilcoxen, whose husband Jay died of cancer not long after the end of the war, described his reactions to chemicals after his return: When my husband first came back from Saudi, to even put gas in his vehicle, he would throw up. To change oil, his hands, it looked like little worms would come out on his hands. And they told him he had an allergic reaction to petroleum products.... Whenever I would use a pine-scented cleaner, when he'd get out of the truck, he would have to get right back in, he couldn't even come in the house. He would just start throwing up.

The biggest thing is the sensitivity to stuff. You used to go out all the time and paint your house and use the thinners and stuff, and now you've got to avoid the use of the thinners. When you pump your own gas, like myself, I've got to turn away so I don't breathe the fumes. The chemical sensitivity is becoming just unreal, and you notice it now. Before, when you would pump gas, you used to stand there and smell the fumes, you know, great, this stuff don't bother me. And now you've got to try to hide and pump at the same time.

My problems with chemical sensitivity began right after the Gulf War. I still cannot pump gas or diesel fuel; my wife pumps it while I sit in the car or truck with the windows rolled up. [When I went back to work], I started having problems that I never had before. The automatic air freshener dispenser in our office was making me sick, as were paint and diesel fumes.

For the veterans suffering from Gulf War syndrome, the chemical sensitivity that they developed in the war is a burden that affects every aspect of their lives, and in particular, their ability to work. Mechanics who have become sensitive to petroleum products can no longer repair cars or other machinery. In my GWS video, Sfc. Terry Dillhyon and Sfc. Roy Twymon both describe perfume exposures that put them in the hospital for a couple of days. Trying to find a job where one can avoid exposure to substances like gasoline, solvents, paint, cleaning products, new carpet, diesel exhaust, perfume, and aftershave lotion quickly becomes an exercise in frustration for these ill veterans whose lives were changed forever by their heroic service in the Gulf War.

Ironworker John Sferazo rushed to Ground Zero as soon as he saw the Twin Towers burning. Ironworkers were in great demand to help cut up the huge iron beams so he worked long hours for the first few days. Even after he had to return to his regular construction job, John worked several hours at the end of each day helping to cut through the debris. The twenty-nine days he spent working on the pile left him with permanent damage to his health.

After breathing in all that toxic dust, I started getting repeated lung infections and pneumonia. Now I have reactive airway disease and what they call COPD, chronic obstructive pulmonary disease. I don't know if I can ever hold any kind of a real job now... . Now what I used to make in a day I have to live on for a week.

Like so many other First Responders or residents of the area who were exposed to the Ground Zero toxins, John is now sensitive to a wide array of common chemical substances: Since $9 / 11$, the smell of gasoline and diesel fuel bothers me so much that I don't get out and even fuel my own vehicles. I don't even want that stuff on my hands because of the odor. Being around the job sites and being around the smell of the diesel and gasoline, I was constantly getting problems with my throat. I would wind up going hoarse, and I would lose my voice.... Now I get headaches and burning in my lungs when I smell cigarette smoke, even though I used to work all the time in an environment in which you would smell welders burning welding wire or burners cutting through iron. Since $9 / 11$, the smell of smoke sometimes makes me gag or feel like throwing up. I can't use cologne or aftershave. I can't take that smell; it causes a burning feeling inside my nostrils. I notice now that some types of cologne have a very, very strong, pungent odor to them. Wherever I smell that kind of smell, I just have to get away from it.

Rachel Hughes was a young artist who volunteered to help unload trucks and pass out sandwiches to workers at Ground Zero, an act of compassion and patriotism that would cost her dearly, as she later described: Within days of the 9/11 attacks, I had a fever and a constant headache; I was also vomiting and feeling dizzy. A bad cough made it hard for me to sleep. I was also having trouble breathing and had considerable chest pain and tightness. One of my worst problems was that large, 
unsightly sores started erupting on my scalp, face, neck, arms, and back. ... About a week after 9/11, I returned to work at my office, which was located about eight blocks north of the Trade Towers. ... There was still thick dust all over our office, so we had to help clean our work spaces ourselves. I wore a surgical mask to work for several weeks because the air smelled horrible and was so thick with dust that it was hard to breathe, despite the assurances from the head of the EPA that the air was safe to breathe. ... Even three months later the smoke in the area was still thick and made my eyes sting. Despite all the smoke and dust and fumes, I continued to work full-time in Lower Manhattan until I was laid off in December 2001 because of the negative effect $9 / 11$ had on business.

My health problems related to the 9/11 toxic exposures have steadily worsened. I frequently have pneumonia or bronchitis. ... Daily headaches are a problem, and I continue to have constant chest pain and pressure. My diagnoses include lung scarring. Chemical sensitivity became a significant problem for me after my exposure to $9 / 11$ toxins. I have had to stop wearing perfume and start using unscented body lotion and shampoo. The chemicals like ammonia or solvents that they use to clean the elevator or halls in my building make it difficult for me to breathe and sometimes give me a migraine. I actually try to hold my breath in the elevator because the cleaning products affect me so strongly.

I have always been a dedicated artist, but I can't paint right now because I'm too sensitive to the paint, even water-based paint. During the four decades that I have been following the field of multiple chemical sensitivity, I have become all too aware of the terrible effect that this little-understood condition has had upon the lives of people from a wide variety of backgrounds and jobs. It has been particularly disturbing to watch the numbers of chemically sensitive Americans grow at such an alarming rate. It is my hope that this rapid proliferation of cases will at last motivate the medical establishment to recognize the seriousness of this condition and give it the attention and research funds necessary to reverse the trend before more and more people end up unable to work and dependent upon government funds to stay alive.

\section{References}

1. Lea Steele (2000) Prevalence and Patterns of Gulf War Illness in Kansas Veterans: Association of Symptoms with Characteristics of Person, Place, and Time of Military Service. Am J Epidemiol 152(10): 992-1002.

Your next submission with Juniper Publishers will reach you the below assets

- Quality Editorial service

- Swift Peer Review

- Reprints availability

- E-prints Service

- Manuscript Podcast for convenient understanding

- Global attainment for your research

- Manuscript accessibility in different formats ( Pdf, E-pub, Full Text, Audio)

- Unceasing customer service

Track the below URL for one-step submission https://juniperpublishers.com/online-submission.php 